\title{
ACCENTUAL VARIATIONS OF SASAK LANGUAGE: A STUDY ON NGENO- NGENE DIALECT OF EAST LOMBOK DISTRICT
}

\author{
Baiq Widia Oktaviana ${ }^{1 *}$, Nur Ahmadi ${ }^{2}$, Arafiq $^{3}$ \\ University of Mataram \\ *e-mail: widiaoktaviana11@gmail.com
}

\begin{abstract}
This study is aimed at finding out the accentual variation of Sasak Ngeno-Ngene dialect in East Lombok district. It tries to describe the accentual variations and their phonological patterns, and the factors which govern the varied patterns. This research used descriptive qualitative method. The source of data was all linguistics expression spoken in four research villages including Pancor village, Kotaraja village, Rarang village, and South Masbagik village. A sample data was recorded from informants who had fulfilled some criteria. The data were collected by observing, storytelling, recording, and note taking. The result of this study shows that every village has their own unique accentual realization. Pancor variant mostly uses the back mid-high /o/sound in realizing the $<\mathrm{a}>$, Kotaraja variant mostly uses the schwa /a/ in its vocabularies, South Masbagik mostly uses the mid front $/ \varepsilon /$ sound in its vocabularies, and Rarang variant sometimes uses the same with others but it differs significantly from another accents through its consonant choices. One accent differs from another accent due to the lexical information, meaning that the accents often vary in the phonemic form they select for lexical representation. This research also found the factors that triggered the accentual variation on ngeno-ngene dialect with regards to the dialectal evolution and social factor.
\end{abstract}

Keywords: accentual variation; phonological patterns; Sasak language

\section{INTRODUCTION}

In Indonesia, many people use their own local language in their daily communication. The local languages in Indonesia are very diverse. The regional languages of West Nusa Tenggara Province itself consist of three languages in which one of them is Sasak language. Sasak language is noted to be diverse in terms of dialectal variation (five major dialects based on geographical border), they are ngeno-ngene dialect, nggetonggeto dialect, meno-mene dialect, meriakmerikudialect, and kuto-kuto dialect used by native speakers of Sasak (Austin, 2000). Ngeno-ngene dialect is spoken in East, Central, West Lombok; Nggetonggete dialect is spoken in North and East Lombok; Meno-menedialect is spoken in Central, West, and East Lombok; Meriakmeriku dialect is spoken in Central and South Lombok; and Kuto-kete dialect is spoken in North Lombok. Austin categorized Sasak language into five dialects, each of which is recognized by native speakers and called for shibboleth phrases that imply 'like that-like this'. Mahsun (2006) classified Sasak language into four dialects, this classification is based on phonological characteristics of each dialect. The four dialects are: Bayan dialect or a-a dialect is mostly spoken in North Lombok, but also spoken in certain areas in West, Central and East Lombok; Pujut dialect or a-e dialect is mostly spoken in West and Central Lombok, but also spoken in certain areas in East Lombok; Selaparang dialect or e-e dialect is mostly spoken in Central and East Lombok, but also spoken in West Lombok; and Aiq Bukak ${ }^{1}$ dialect or a-o dialect is spoken in Central and East Lombok. Mahsun classification is taken here as classification of accentual variation instead of dialectal classification (see. Wells, 1982 vol.1).

In Sasak language there are eleven vowels, including: [i], [I], [e], [e], [a], [i],

\footnotetext{
1 The spelling is also observed to vary. Some variations are observed: Aik Bukak, Aiq Bukaq, Aiq Bukak and Aik Bukaq.
} 
$[ə],[\mathrm{u}],[\mathrm{U}],[\mathrm{o}]$, and [o]. And also there are seventeen consonants, they are: $[\mathrm{p}]$, $[\mathrm{b}],[\mathrm{m}],[\mathrm{t}],[\mathrm{d}],[\mathrm{n}],[\mathrm{c}],[\mathrm{j}],[\mathrm{n}],[\mathrm{s}],[\mathrm{r}],[1]$, $[\mathrm{k}],[\mathrm{g}],[\mathrm{y}],[\mathrm{h}]$, and [?] (Aridawati et al., 1995). When learning a new language especially English, the Sasak speaker face difficulties, one of which is the problem of pronouncing consonant. According to Arafiq, et al, (2020) there are two English sounds found to be problems by Sasak speaking learners, both of which are consonants. The sounds are fricative labiodentals voiceless /f/ and fricative labiodentals voiced /v/. For example /st $\Lambda \mathrm{f} /$ pronounced as /st $\Lambda \mathrm{p} /$ and in /weiv/ pronounced as /weip/. This may occurs because /f/ and /v/ do not exist as the consonant sounds in Sasak language.

Sasak is a local language spoken by Sasak tribe and it is mostly used as vernacular among family and rural communication. Sasak language, especially Sasak Ngeno-ngene dialect which is mostly spoken in East Lombok has its own accentual manifestation among speakers in different area in Lombok. For example, we may cite our observation in the use of [ə] and [o] sound. In Kotaraja village, the people mostly used the [ə] sound to realize the grapheme $<\mathrm{a}>$, but on the other hand, the Pancor speaker realize it as [o] sound. According to Ahmadi (2017) in his article entitles "Harmoni Vokal Dialek Ngeno-Ngene Pancor", the /o/ sound in Pancor accent occurs due to raising process, the low front vowel /a/ rises to the back mid-high to become /o/. the raising is phonologically motivated for vowel harmony. Thus the word batu 'stone', ragi 'ingredient' are are systematically realized as /botu/ and /rogi/ because the following syllable contains [+high] sound (see further Kenstowicz, 1979 and Peng, 2013). Inspite of the fact, the people in East Lombok mostly use Ngeno-ngene dialect in their daily communication, but their accentual variation is significant. The term accent refers phonetic manifestation of lexical sets (items) as is used by Wells (1982). In this way, using the same lexical item $<$ maik> /mai?/ for instance, we find variation between Kotaraja and Pancor. The same lexicon in Kotaraja Village is pronounced [məI?], in Rarang Village it realized as [maI?], in South Masbagik Village it pronounced as [meIP] and in Pancor Village it surfaced as [moI?].

The term accent and dialect are often used synonymously in everyday speech, but actually they are different from one another. Accent refers to differences in pronunciation, whereas dialect refers to differences in phonology, grammar and vocabulary (Edward, 2008, p.380) ${ }^{2}$. The lexical differences between several dialects are belong to dialectal variation, for example the speakers of Sasakngenongene dialect will use the lexical [loyo] cacing 'worm', while the speakers of SasakKuto-kete dialect will use the lexical [gumbər] cacing 'worm'. On the other hand, the different in pronunciation of one dialect is belongs to accentual variation. As an example, the speakers of Sasak Ngeno-ngene dialect in Kotaraja village will say [əI?] 'water' while the speakers of Sasak Ngeno-ngene dialect in South Masbagik village will say [EI?] 'water'. In this case, they are use different pronunciation to pronounced /aiq/. In this study, the writer is interesting to do a research in the accentual variation in order to enrich people's understanding especially in the variety of accent.

\footnotetext{
Mahsun (2006) dialectal classification thus qualifies the definition of accent and it is thus taken as such in this paper.
} 
Table 1. Variety of accents of SasakNgeno-ngene dialect in four villages

\begin{tabular}{|c|c|c|c|}
\hline Kotaraja Variant & Rarang Variant & South Masbagik Variant & Pancor Variant \\
\hline [məI?] 'delicious' & [mal?] 'delicious' & [mel?] 'delicious' & [mol?] 'delicious' \\
\hline [əIP] 'water' & [aIP] 'water' & [EIP] 'water' & [oI?] 'water' \\
\hline [əрI] 'fire' & [əpI] 'fire' & [epI] 'fire' & [opI] 'fire' \\
\hline
\end{tabular}

The data above shows the variety of accents of Sasak Ngeno-ngene dialect in three words maik, aik, and api. The accentual variation that occurs in some research villages leads the writer to do a research about accentual variation. This study is aimed to (a) find out the accentual variation of SasakNgeno-ngene dialect in East Lombok district (b) find out how accents differ in SasakNgeno-ngene dialect (c) find out the factors that triggering the accentual variation in SasakNgeno-ngene dialect.

\section{REAEARCH METHOD Research Design}

This research was categorized as qualitative research using accentual variation as the object of the study. The data of this research is all linguistics expression spoken by eight informants in four research villages (Kotaraja, Pancor, Rarang and South Masbagik village). A sample of language used by native speakers of Ngeno-ngene dialect in East Lombok was recorded from eight informants in four research villages (two informants (one man and one woman) in each village research). This research used informants on several criteria:

1. They are women or men who are born and grow up in one of the research villages (Kotaraja, Pancor, Rarang, and South Masbagik) in East Lombok.

2. The age of informants is between 2050 years old.

3. The informants are active and fluently in using the Sasak Language NgenoNgene dialect

4. The informants must have a comprehension of the language

5. The informants have good articulation.

\section{Method of Data Collection}

There are four methods used by the writer to collect the data. They are observing, storytelling, recording and note taking. Observing method is a process of collecting data in which the writer comes to the field and seek the qualified informants. In this case, the writer came to four research villages located in different sub-districts in East Lombok district, those are: Kotaraja Village is located in Sikur sub-district, Rarang Village is located in Terara sub-district, South Masbagik Village is located in Masbagik sub-district, and Pancor Village is located in Selong sub-district to seek the qualified informants. In each village, the researcher chooses two informants, a man and a woman. The researcher observed them who is fluently speaking Sasak Ngenongene dialect and fulfilling the criteria. The researcher collected the information from the informants through storytelling. In this case, the researcher asked the informants to tell about the celebration of the Independence Day in each village. The researcher recorded the informants' voices using a recorder. Then the researcher transcribed the data into written data and phonetic transcription. The researcher noted the words that were considered important during the research. In addition as a Sasak native speakers of Ngeno-ngene dialect, the writer use her linguistic intuition to test the acceptability of the data delivered by the informants.

\section{Data Analysis}

The spoken data gained from informants were transcribed into written data. After that, the written data were transcribed into phonetic transcription 
using IPA symbols. In order to seek the accentual variation, the data were divided into four groups of accents. This study also deliver the word list as the comparison words to compared between accents. The researcher describe either the accentual variation occurs in vowel context or consonant context, described about how accents differ, explains the factor that triggering the accentual variation in SasakNgeno-ngene dialect in East Lombok.

\section{FINDINGS AND DISCUSSION}

The accentual variation found in Sasakngeno-ngene dialect spoken in East Lombok

In order to make it easier to compare between accents, in this section, this study provided a list of words below that be used to compare one accent with another. This word list is only for comparison without claiming it as the original form of Sasak Language.

Table 2. The list of words that used to compare between accents

\begin{tabular}{cc}
\hline Word & Meaning \\
\hline$/$ jari/ & so \\
\hline$/$ laguk/ & but \\
\hline$/$ arak/ & there is/there are \\
\hline$/$ karung/ & sack \\
\hline$/$ kanca/ & with \\
\hline$/$ lain/ & other \\
\hline$/$ bau/ & able \\
\hline$/$ masi/ & still \\
\hline$/$ toak/ & old age \\
\hline$/$ gati/ & very \\
\hline$/$ mauk/ & get \\
\hline$/$ tebagi/ & be divided \\
\hline$/$ marak/ & like/as \\
\hline$/$ sugul/ & go out \\
\hline$/$ luar/ & outside \\
\hline$/$ lapar/ & hungry \\
\hline &
\end{tabular}

The comparison will be:

Table 3. Table of comparison accentual variation of Sasakngeno-ngenedialect

\begin{tabular}{|c|c|c|c|c|c|}
\hline No. & Word & Pancor Variant & Kotaraja Variant & South Masbagik Variant & Rarang Variant \\
\hline 1. & /jari/ & [jorI] & [jərI] & [jerI] & [jərI] \\
\hline 2. & /laguk/ & [logu?] & [lagu?] & legu? & lagu? \\
\hline 3. & /arak/ & [ərə?] & [ara?] & [ara?] & [ara?] \\
\hline 4. & /karung/ & [karən] & [karəy] & [karuy] & [karuy] \\
\hline 5. & /kanca/ & [kəncə] & [kəncə] & [kence] & [kəncə] \\
\hline 6. & /lain/ & [loIn] & [ləIn] & [leIn] & [lain] \\
\hline 7. & $/ \mathrm{bau} /$ & [bou] & [bou] & [beu] & [bəu] \\
\hline 8. & /masi/ & [mosI] & [məsI] & [mesI] & [masI] \\
\hline 9. & /toak/ & [toə?] & [toa?] & [toa?] & [toa?] \\
\hline 10. & /gati/ & [gotI] & [gətI] & [getI] & [gətI] \\
\hline 11. & /mauk/ & [mou?] & [mou?] & [meu?] & [mau?] \\
\hline 12. & /tebagi/ & [təbogI] & [təbəgI] & [təb\&gI] & [təbəgI] \\
\hline 13. & /marak/ & [mərə?] & [mara?] & [mara?] & [mara?] \\
\hline 14. & /sugul/ & [sugul] & [sugul] & [sugul] & [sugun] \\
\hline 15. & /luar/ & [luar] & [luar] & [luar] & [luah] \\
\hline 16. & /lapar/ & [lapar] & [lapar] & [lapar] & [lapah] \\
\hline
\end{tabular}


Based on Table 3 the accentual variation that found in Sasakngenongenedialect divided into two forms, accentual variation in vowel and accentual variation in consonant.

\section{A. Accentual Variation in Vowel}

1. The lexical /jari/ is represented differently. In Pancor variant it is represented as [jorI], in Kotaraja and Rarang variant it is represented as [jorI], and in South Masbagik variant it is interpreted as [jeri].

2. The lexical /laguk/ is represented differently. In Pancor variant it is represented as [logu?], in Kotaraja and Rarang variant it is represented as [lagu?], and in South Masbagik variant it is represented as [legu?].

3. The lexical /arak/ is represented differently. In Pancor variant, it is represented as [ərə?] while in Koraraja, Rarang, and South Masbagik variant, it is represented as [ara?].

4. The lexical/karung/ is represented differently. In Pancor variant, firstly this study found that /karung/ is represented as [karon], but after re-confirming it was found that the actual pronunciation of /karung/ was [karəy]. In Kotaraja variant it is also represented as [karəy], while in Rarang and South Masbagik variant it is represented as [karuy].

5. The lexical $/ \mathrm{kanca} /$ is represented differently. In Pancor, Kotaraja, and Rarang variant, it is represented as [kəncə], while in South Masbagik variant it is represented as [kence].

6. The lexical /lain/ is represented differently in four villages. In Pancor variant, it is represented as [loIn], in Kotaraja variant it is represented as [ləIn], in Rarang variant it is represented as [lain], and in South Masbagik it is represented as [licin].

7. The lexical /bau/ is represented differently. In Pancor variant, it is represented as [bou], in Kotaraja and Rarang variant it is represented as [bəu], and in South Masbagik variant it is represented as [beu].

8. The lexical /masi/ is represented differently in four villages. In Pancor variant, it is represented as [mosI], in Kotaraja variant it represented as [məsI], in Rarang variant it is represented as [masI], and in South Masbagik variant it is represented as [mesI].

9. The lexical/toak/ is represented differently. In Pancor variant, it is represented as [toə?], in Kotaraja, Rarangt and South Masbagik variant it is represented as [toa?].

10. The lexical /gati/ is represented differently. In Pancor variant, it is represented as [gotI], in Kotaraja and Rarang variant it is represented as [gətI], and in South Masbagik it is represented as [getI].

11. The lexical /mauk/ is represented differently in four villages. In Pancor variant, it is represented as [mou?], in Kotaraja variant it is represented as [məu?], in Rarang variant it is represented as [mau?], and in South Masbagik variant it is represented as [meu?].

12. The lexical/tebagi/ is represented differently. In Pancor variant, it is represented as [təbogI], in Kotaraja and Rarang variant it is represented as [təbəgI], and in South Masbagik it is represented as [təbøgI].

13. The lexical/marak/ is represented differently. In Pancor variant, it is represented as [mərə?], in Kotaraja, Rarang and South Masbagik it is represented as [mara?]. 


\section{B. Accentual Variation in Consonant}

1. The lexical/sugul/ is represented differently. In Pancor, Kotaraja, South Masbagik variant, it is represented as [sugul], while in Rarang variant it is represented as [sugun].

2. The lexical /luar/ is represented differently. In Pancor, Kotaraja, South Masbagik variant, it is represented as [luar], while in Rarang variant it is represented as [luah].

Based on the data above, the alternation of sounds that occurs in each accent will be explained below:

\section{1) Pancor Variant}

Table 4.A list of words containing the change of /a/ becomes /o/ in Pancor variant

\begin{tabular}{|c|c|c|}
\hline Word & Word Transcription & Pancor Variant \\
\hline jari & [jarI] & [jorl] \\
\hline mauq & [mau?] & [mou?] \\
\hline tebagi & [təobagI] & [təbogI] \\
\hline lain & [la $\underline{\mathrm{a} I n]}$ & [lo In] \\
\hline bau & [bau] & [bou] \\
\hline masi & [masI] & [mosI] \\
\hline gati & [gat & [gotI] \\
\hline laguq & [lagu?] & [logu?] \\
\hline
\end{tabular}

The above data shows how the /a/ sound of the words jari, mauq, tebagi, lain, bau, masi, gatiand laguq was changed into /o/ sound in Pancor Variant. The low front vowel /a/ is rising to the back mid-high position to become /o/, so that the alternation of the sounds is drawn in the following:

Table 5.The alternation of sound /a/ becomes

\begin{tabular}{|c|c|c|}
\hline \multicolumn{3}{|c|}{ /o/ in Pancor Variant } \\
\hline & $\begin{array}{l}\text { Front } \\
\text { (Word) }\end{array}$ & Back (Pancor Variant) \\
\hline mid-high & e & $\rightarrow 0$ \\
\hline low & $a$ & - \\
\hline
\end{tabular}

In another case, this research found that the /a/ sound also changed into /a/ sound in some words. Let's see the example below.
Table 6.A list of words containing the change of /a/ becomes /a/ in Pancor variant

\begin{tabular}{|c|c|c|}
\hline Word & Word Transcription & Pancor Variant \\
\hline kanca & [kanca] & [kə⿹nc只] \\
\hline araq & [ara $\underline{\operatorname{ara}}$ & [마무 $P]$ \\
\hline maraq & [mara?] & [məra $\underline{\partial}$ ?] \\
\hline toaq & [toa? $]$ & [tog? $]$ \\
\hline
\end{tabular}

The alternation of the sounds is drawn in the following:

Table 7. The alternation of sound /a/ becomes /a/

\begin{tabular}{ccc}
\hline & Front & Central \\
\hline Mid & $\varepsilon$ & $\boldsymbol{P}^{\partial}$ \\
\hline Low & a & - \\
\hline
\end{tabular}

\section{2) Kotaraja Variant}

Table 8.A list of words containing the change of /a/ becomes /a/ in Kotaraja variant

\begin{tabular}{|c|c|c|}
\hline Word & $\begin{array}{c}\text { Word } \\
\text { Transcription }\end{array}$ & $\begin{array}{c}\text { Kotaraja } \\
\text { Variant }\end{array}$ \\
\hline Jari & [jarl] & [jörI] \\
\hline Mauq & [mau?] & [mou?] \\
\hline Tebagi & [təbagl] & [təboggI] \\
\hline Lain & [la & [lo $\underline{\mathrm{g} I n}]$ \\
\hline Bau & [bau] & [bogu] \\
\hline Masi & [masI] & [môsI] \\
\hline Gati & [gatI] & [gôtI] \\
\hline Kanca & [kanca] & [kə̄nco] \\
\hline
\end{tabular}

The above data shows how the /a/ sound of those words was changed. The low front vowel /a/ is rising to the back mid-central position becomes $/ \partial /$, so that the alternation of the sounds is drawn in the following:

Table 9. The alternation of sound /a/ becomes /a/ in Kotaraja Variant

\begin{tabular}{ccc}
\hline & Front & Central \\
\hline Mid & $\varepsilon$ & - \\
\hline Low & $\mathrm{a} \longrightarrow$ & - \\
\hline
\end{tabular}

In addition, the $/ \mathrm{u} /$ sound also changes into schwa in Kotaraja variant. Let see the example below.

Table 10.A list of word containing the change of $/ \mathrm{u} /$ becomes $/ \mathrm{a} /$ in Kotaraja variant

\begin{tabular}{ccc}
\hline Word & $\begin{array}{c}\text { Word } \\
\text { Transcription }\end{array}$ & $\begin{array}{c}\text { Kotaraja } \\
\text { Variant }\end{array}$ \\
\hline Karung & {$[$ karuy $]$} & {$[$ karog $]$} \\
\hline
\end{tabular}


The above data shows how the $/ \mathrm{u} /$ sound in the last syllable of those words was changed into schwa sound. The back high vowel $/ \mathrm{u} /$ is lowering to the back midcentral position becomes / $/$. The alternation of the sounds is drawn in the following:

Table 11. The alternation of sound $/ \mathrm{u} /$ becomes /a/ in Kotaraja Variant

\begin{tabular}{ccc}
\hline & Central & Back \\
\hline High & - & $\longrightarrow \mathrm{u}$ \\
\hline Mid & $\partial$ & o \\
\hline
\end{tabular}

\section{3) South Masbagik Variant}

Table 12. A list of words containing the change of /a/ becomes / $\varepsilon /$ in South Masbagik

\begin{tabular}{|c|c|c|}
\hline Word & $\begin{array}{c}\text { Word } \\
\text { Transcription }\end{array}$ & $\begin{array}{c}\text { South } \\
\text { Masbagik } \\
\text { Variant }\end{array}$ \\
\hline jari & [jarl] & [jerrI] \\
\hline mauq & [mau?] & [mgu?] \\
\hline tebagi & [təbagI] & [təb $\underline{\varepsilon g I}]$ \\
\hline lain & [la & [l툐 \\
\hline bau & [bau] & [buu $]$ \\
\hline masi & [masI] & [mesI] \\
\hline gati & [gati] & [ge्tI] \\
\hline laguq & [lagu?] & [legu?] \\
\hline kanca & [kanca] & [kence] \\
\hline
\end{tabular}

The above data shows how the /a/ sound of those words was changed into $/ \varepsilon /$ sound. Unlike the three other accents, the $/ \varepsilon /$ sound is the own characteristic of Masbagik accent. The low front vowel /a/ is rising to the front mid-position becomes $/ \varepsilon /$. The alternation of the sounds is drawn in the following:

Table 13. The alternation of sound /a/ becomes / $/$ / in South Masbagik Variant

\begin{tabular}{cc}
\hline & Front \\
\hline Mid & $\varepsilon$ \\
\hline Low & a \\
\hline
\end{tabular}

\section{4) Rarang Variant}

Table 14.A list of words containing the change of $/ \mathrm{a} / \mathrm{becomes} / \mathrm{\partial} /$ in Rarang variant

\begin{tabular}{ccc}
\hline Word & $\begin{array}{c}\text { Word } \\
\text { Transcription }\end{array}$ & $\begin{array}{c}\text { Rarang } \\
\text { Variant }\end{array}$ \\
\hline jari & {$[$ jarl] } & [jörI $]$
\end{tabular}

\begin{tabular}{|c|c|c|}
\hline tebagi & [təbagagI] & [təbog \\
\hline bau & [bau] & {$[\mathrm{b} \underline{\partial} \mathrm{u}]$} \\
\hline gati & [gatI] & [gattI] \\
\hline kanca & [kanca] & [kəonco] \\
\hline
\end{tabular}

The above data shows how the /a/ sound of those words was changed. The low front vowel /a/ is raising to the back mid-central position becomes / $/ \mathrm{l}$. The alternation of the sounds is drawn in the following:

Table 15.The alternation of sound /a/ becomes

\begin{tabular}{ccc}
\multicolumn{3}{c}{$/ \mathrm{a} /$} \\
\hline & Front & Central \\
\hline Mid & $\varepsilon$ & $\partial$ \\
\hline Low & $\mathrm{a} \longrightarrow$ & - \\
\hline
\end{tabular}

Unlike three other accents, Rarang variant is the accent that has a different way to mention several consonants sounds in some words. Look at the example below about the $/ \mathrm{r} /$ sound in the word luar and laparbecomes $/ \mathrm{h} /$ sound in Rarang variant.

Table 16.A list of words containing the change of $/ \mathrm{r} /$ becomes $/ \mathrm{h} /$ in Rarang variant

\begin{tabular}{ccc}
\hline Word & $\begin{array}{c}\text { Word } \\
\text { Transcription }\end{array}$ & $\begin{array}{c}\text { Rarang } \\
\text { Variant }\end{array}$ \\
\hline luar & {$[$ luar] } & {$[$ luah $]$} \\
\hline lapar & [lapar] & {$[$ lapah $]$} \\
\hline
\end{tabular}

The approximant alveolar voiced $/ \mathrm{r} /$ in the words luarand laparwere changed into fricative glottal voiceless $/ \mathrm{h} /$. The alternation of the sounds is drawn in the following:

Table 17.The alternation of sound $/ \mathrm{r} /$ becomes

\begin{tabular}{ccccc}
\hline & \multicolumn{2}{c}{ Alveolar } & \multicolumn{2}{c}{ Glottal } \\
& \multicolumn{2}{c}{ Alv } & & \\
\cline { 2 - 4 } & $+\mathrm{V}$ & $-\mathrm{V}$ & $+\mathrm{V}$ & $-\mathrm{V}$ \\
\hline Approximant & $\mathrm{r}$ & & & \\
\hline Fricative & $\mathrm{z}$ & $\mathrm{S}$ & & $\mathrm{h}$ \\
\hline
\end{tabular}

Rarang variant also has a different way of representing the /1/ sound in the word sugul, it uses the $/ \mathrm{n} /$ sound.

Table 18.A list of word containing the change of $/ 1 /$ becomes $/ \mathrm{n} /$ in Rarang variant

\begin{tabular}{ccc}
\hline Word & $\begin{array}{c}\text { Word } \\
\text { Transcription }\end{array}$ & $\begin{array}{c}\text { Rarang } \\
\text { Variant }\end{array}$ \\
\hline sugul & [sugul] & [sugun] \\
\hline
\end{tabular}


In the word sugul, the alveolar lateral voiced /1/ changes into alveolar nasal-voiced $/ \mathrm{n} /$. The alternation of the sounds is drawn in the following:

Table 19. The alternation of sound /1/ becomes

\begin{tabular}{ccccc} 
& \multicolumn{2}{c}{$/ \mathrm{n} /$} & \\
& \multicolumn{2}{c}{ Lateral } & \multicolumn{2}{c}{ Nasal } \\
\cline { 2 - 5 } & $+\mathrm{V}$ & $-\mathrm{V}$ & $+\mathrm{V}$ & $-\mathrm{V}$ \\
\hline Alveolar & $\mathrm{1}$ & & $\mathrm{n}$ & \\
\hline
\end{tabular}

How accents differ in Sasakngenongenedialect spoken in East Lombok

The accentual variation that

found in East Lombok occurs due to lexical distribution, means that the accents often vary in the phonemes they select for lexical representation. The accents may use the same or different phoneme to represent particular words or morphemes.

1. In the words lain, masi and maukeach accent use the different phoneme to its lexical representation. In this case each accent uses the different phoneme to representing the [a] sound in those words above.Pancor variant uses the phoneme /o/, those word become [loIn] [mosI] [mou?], Kotaraja variant uses the phoneme /a/, those words become [ləIn] [məsI] [məu?], Rarang variant uses the phoneme /a/, those words become [laIn] [masI] [mau?], and South Masbagik uses the phoneme / $\varepsilon /$, those words become [leIn] [mesI] [meu?].

- $[1(0, \partial, a, \varepsilon) \operatorname{In}]$

- $[\mathrm{m}(\mathrm{o}, \partial, \mathrm{a}, \varepsilon) \mathrm{sI}]$

- $[\mathrm{m}(\mathrm{o}, \partial, \mathrm{a}, \varepsilon) \mathrm{u}$ ?]

2. In the words jari, laguk, bau, tebagi, and gatieach accent uses the different phoneme to its lexical representation. In this case each accent uses the different phoneme to representing the [a] sound in those words above. Pancor variant uses the phoneme $/ \mathrm{o} /$, those words become [jorl] [logu?] [bou] [təbogI] [gotI], Kotaraja variant and Rarang variant use the same phoneme /ə/, those words become [jərI] [logu?] [bəu] [təbəgI] [gətI] and South Masbagik uses the phoneme $/ \varepsilon /$, those words become [jerl] [legu?] [beu] [təbegI] [getI].

- $[\mathrm{j}(0, \partial, \varepsilon) \mathrm{rI}]$

- $[1(0, \partial, \varepsilon) g u ?]$

- $[\mathrm{b}(0, \partial, \varepsilon) \mathrm{u}]$

- $[\operatorname{təb}(0, \partial, \varepsilon) \mathrm{gI}]$

- $[\mathrm{g}(0, \partial, \varepsilon) \mathrm{tI}]$

3. In the word karung, each accent uses the different phoneme to its lexical representation. In this case the two accents use the different phoneme, while two other accents use the same phoneme to representing the $[\mathrm{u}]$ sound in the last syllabe in the word karung above. Pancor variant and Kotaraja variant use the phoneme /ə/, becomes [karəy] while Rarang variant and South Masbagik variant use the same phoneme $/ \mathrm{u} /$, so that the word karungbecomes [karuy].

- $[\operatorname{kar}(\partial, \mathrm{u}) \mathrm{y}]$

4. In the words toak, arak and marakonly Pancor variant uses the phoneme /a/ to representing the [a] sound in those words above, while the three other accents use the phoneme /a/. Pancor variant uses the phoneme /o/, those words become [toə?] [ərə?] [mərə?], while Kotaraja variant, Rarang variant and South Masbagik variant use the same phoneme /a/, those words become [toa?] [ara?] [mara?].

- $[\operatorname{to}(\partial, a) ?]$

- $[(\partial, a) r(\partial, a) P]$

- $[\mathrm{m}(\partial, \mathrm{a}) \mathrm{r}(\partial, \mathrm{a}) \mathrm{P}]$

5. In the word kanca only South Masbagik variant uses the phoneme $/ \varepsilon /$ to representing the [a] sound, while the three other accents use the phoneme /ə/. Pancor variant, Kotaraja variant, and Rarang variant use the same phoneme $/ \partial /$, the word [kanca] becomes [kəncə], and South Masbagik uses the phoneme $/ \varepsilon /$, the word [kanca] becomes [kence].

- $[\operatorname{kenc}(\partial, \varepsilon)]$ 
6. In the words luarand lapar, only Rarang variant uses the phoneme $/ \mathrm{h} /$ to representing the $[\mathrm{r}]$ sound in those words above, while the three other accents use the phoneme /r/. Pancor, Kotaraja, and South Masbagik use the same phoneme $/ \mathrm{r} /$, those words become [luar] [lapar], and Rarang variant uses the phoneme $/ \mathrm{h} /$, so those words become [luah] [lapah].

- $\quad[\operatorname{lua}(\mathrm{r}, \mathrm{h})]$

- $\quad[\operatorname{lapa}(\mathrm{r}, \mathrm{h})]$

7. In the word sugul, only Rarang variant accent uses the phoneme $/ \mathrm{n} /$ to representing the [1] sound in the word sugul, while the three other accents use the phoneme $/ 1 /$. Pancor, Kotaraja, and Masbagik use the same phoneme /1/, that word becomes [sugul], and Rarang variant uses the phoneme $/ \mathrm{n} /$, so that word becomes [sugun].

- $[\operatorname{sugu}(1, n)]$

\section{Factor that triggering the accentual variation in Sasakngeno-ngenedialect spoken in East Lombok}

This study shows the factor that triggering the accentual variation are the dialect evolution factor and social factor. Dialect evolution includes internal and external factor, while social factor related to presence of nobles in a village. SasakPrilingual is the original form of the lexical in Sasak Language before those lexical differentiate into dialects form. It indicates the original form of the Sasak language underwent an evolution which caused changes or differences in the level of dialect or accent. The dialect evolution is causing by external and internal factor. According to external factor, the SasakPrilingual was divided into several dialects is thought to have as a result of the influence of the Karangasem Kingdom of Bali over the Selaparang Kingdom in Lombok. In addition, according to internal factor, the dialects were built due to its internal innovation. The internal innovation of dialect (internal factor) and the influence of other culture in the past time (external factor) are able to make accentual variation occurs, especially in ngeno-ngene dialect. The dialect evolution is causing the accentual variation in the form of phonological changes. It includes vowel and consonant changes.

This study found that in the words masi, lain, and mauk the accentual variation is really happen. It means that, from many other words that have been discussing above, only on those three words we are able to see the four different accents are differ from another, especially on its vowel representation.

According to internal factor, the dialects were built due to its internal innovation. Internal innovation means that the lexical of dialect was built from the lexical form of the earlier dialect. The internal innovation also occurs here. The earlier form of the word /mauk/ is [mau?]. The word [mau?] then evolved into several variations; [mau?],[mou?],[mou?],[meu?] through partial regressive assimilation process. The same process also occurs to the words [masI] and [laIn].

Furthermore, in this case the variations of the vowel representation also occur due to raising process. The vowel /a/ in the words [mau?] [masI] and [laIn] were changed into another form due to raising process. In Pancor variant, the low front vowel /a/ rises to the back mid-high to become /o/, so that, the words [mau?] [masI] and [laIn] become [mou?] [mosI] and [loIn]. In Kotaraja variant, the low front vowel /a/ rises to central mid vowel become $/ \partial /$, so that, the words [mau?] [masI] and [laIn] become [məu?] [məsI] and [ləIn]. In Rarang variant, in the words [mau?] [masI] and [laIn] the vowel /a/ does not change, it is still use vowel /a/. In South Masbagik variant, the low front vowel /a/ rises to front mid vowel / $\varepsilon /$, so that, the words [mau?] [masI] and [laIn] become [meu?] [mesI] and [leIn]. The rise schema of vowel [a] will be: 


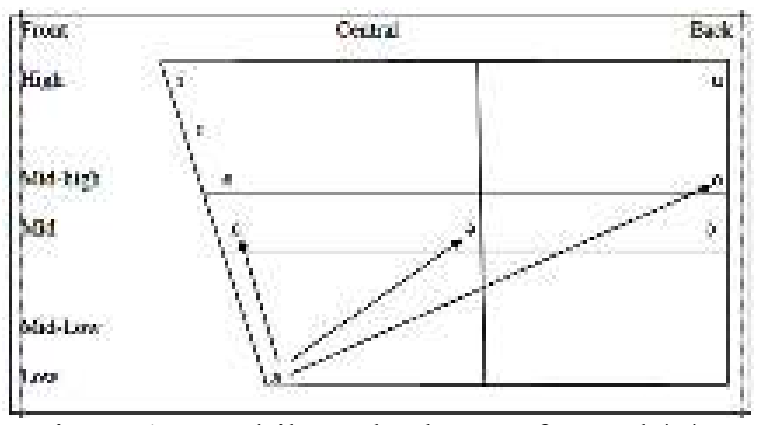

Figure 1. Quadrilateral schema of sound /a/ becomes $/ \mathrm{a} / / \mathrm{o} /$ and $/ \varepsilon /$

The study found that only Rarang variant represented [lapar] as [lapah], the [r] sound changes into the $[\mathrm{h}]$ sound due to consonant change process, [approximant $][+$ voiced $]>$ [fricative $][-$ voiced $]=[\mathrm{r}]>[\mathrm{h}]$. Rarang variant also represented [sugul] as [sugun], the [1] sound changes into the [n] sound, [lateral] $[+$ voiced $]>[$ nasal $]$ [voiced $]=[1]>[\mathrm{n}]$. The phonological rule of the data will be:

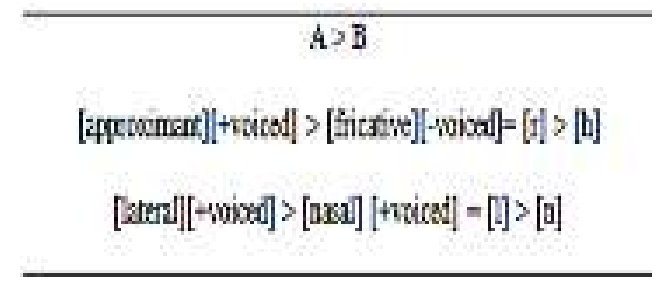

Figure $2 . / \mathrm{r} /$ becomes $/ \mathrm{h} /$ and $/ \mathrm{l} /$ becomes $/ \mathrm{n} /$

In addition, social class can be seen as the factor that triggering the accentual variations. In villages of many nobles, the varieties of accents used are similar, this is because the nobles on those villages mostly use Sasakhalusand tend to maintain their language in order to preserving the language. As for villages of few noble, it shows language innovation, especially in accent variations. This change can take place because of the influence of language acculturation from one village to another.

\section{CONCLUSION}

Study finds that every village has their own unique accent. Pancor variant mostly uses the $o$ sound in its vocabularies, Kotaraja variant mostly uses the schwa $a$ in its vocabularies, South Masbagik mostly uses the $\varepsilon$ sound in its vocabularies, and Rarang variant sometimes uses the same with others but it is much differs from another accents through its consonant choices. Study finds that one accent differ to another accent due to due to lexical distribution, means that the accents often vary in the phonemes they select for lexical representation. In this case, the accents sometimes use the same with others, sometimes they're use different phoneme too.

This study shows the factor that triggering the accentual variation are the dialect evolution factor and social factor. The internal innovation of dialect and the influence of other culture in the past time are able to make accentual variation occurs, especially in ngeno-ngene dialect. The dialect evolution is causing the accentual variation in the form of phonological changes. It includes vowel and consonant change.

\section{REFERENCES}

Ahmadi, N. (2017). Harmoni Vokal Dialek Ngeno-Ngene Varian Pancor. Seminar Nasional Bahasa Ibu (pp. 1576-1588). Denpasar: Udayana University Press.

Ahmadi, N. (2020). Introducing Phonology (Draft).

Akmajian, A., Demers, R. A., Farmer, A. K., \& Harnish, R. M. (2001). Linguistics: An Introduction to Language and Communication (fifth edition). The MIT Press.

Arafiq. (2020). The Syntax of Personal Pronouns in the Bima Language. International Linguistics Research , 13-21.

Arafiq, Yusra, K., \& Saputra, A. (2020). Mapping Students' Phonological Problems in Pronouncing English Sounds: A Study on Speakers of Local Languages in West Nusa Tenggara. Proceedings of the 1st Annual Conference on Education and Social Sciences (ACCESS 2019) (pp. 199-202). Atlantis Press SARL. 
Aridawati, I. A., Thoir, N., Purwa, I. M., \& Sutana, D. (1995). Struktur Bahasa Sasak Umum. Jakarta: Pusat Pembinaan dan Pengembangan Bahasa.

Brinton, L. J., \& Brinton, D. M. (2010). The Linguistics Structure of Modern English. Amsterdam/Philadelphia: John Benjamins Publishing Company.

Bunyamin. (2017). Berkenalan dengan Sasambo. Jakarta Timur: Badan Pengembangan dan Pembinaan Bahasa.

Creswell, J. W. (2014). Research design: qualitative, quantitative, and mixed method approaches. SAGE Publications.

Finegan, E. (2008). Language Its Structure and Use. Michael Rosenberg.

Hansson, G. Ó. (2010). Consonant Harmony : Long-Distance Interaction in Phonology. University California Press.

Jeffers, Robert J. and Lehiste. 1979. Principle and Method for Historical Linguistic. Cambridge, Massachusetts and London. England: The MIT Press.

Kenstowicz, Michael and Charles Kisseberth, 1979. Generative Phonology. Florida: Academic Press.

Krämer, M. (2003) Vowel Harmony and Correspondence Theory: Studies in Generative Grammar. Berlin: Mouton de Gruyter Copyright.
Mahsun. (2006). Kajian Dialektologi Diakronis Bahasa Sasak di Pulau Lombok. Yogyakarta: Gama Media.

McMahon, A. (2002). An Introduction to English Phonology. Great Britain: Edinburgh University Press.

Muhammad. (2011). Paradigma Kualitatif Penelitian Bahasa. Yogyakarta: Liebe Book Press.

Peng, Long.2013. Analyzing Sound Patterns. USA: Cambridge University Press.

Peter K. Austin (2012). Tense, aspect, mood and evidentiality in Sasak, eastern Indonesia. In Stuart McGill \& Peter K. Austin (eds) Language Documentation and Description, vol 11. London: SOAS. pp. 231251.

Peter K. Austin. (2013) NUSA: Linguistic Studies of Languages in and Around Indonesia. University of London.

http://hdl.handle.net/10108/71804

Podile, K. (2002). The Depedency Relations Within Xhosa Phonological Process. MA-Thesis, University of South Africa.

Walker, R. (2006). Gradualness and FellSwoop Derivations. London: Edward Arnold.

Wardhaugh, R. (2006). An Introduction to Sociolinguistic (fifth edition). Blackwell Publishing.

Wells, J. (1982). Accents of English 1 An Introduction. Cambridge University Press. 